medRxiv preprint doi: https://doi.org/10.1101/2020.04.15.20063578; this version posted April 20, 2020. The copyright holder for this preprint

(which was not certified by peer review) is the author/funder, who has granted medRxiv a license to display the preprint in perpetuity.

This article is a US Government work. It is not subject to copyright under 17 USC 105 and is also made available for use under a CCO license.

\title{
Computational Modeling of Attentional Impairments in Disruptive Mood Dysregulation and Attention Deficit/Hyperactivity Disorder
}

Simone P. Haller, DPhil*t1, Joel Stoddard, MD, MAS*2, David Pagliaccio, $\mathrm{PhD}^{3}$, Hong Bui, BA ${ }^{1}$, Caroline MacGillivray, BA ${ }^{1}$, Matt Joes, $\mathrm{PhD}^{4}$, \& Melissa A. Brotman, $\mathrm{PhD}^{1}$

*The authors contributed equally

${ }^{1}$ Emotion and Development Branch, National Institute of Mental Health, National Institutes of Health, 9000 Rockville Pike, Bethesda, MD, 20892

${ }^{2}$ Pediatric Mental Health Institute, Children's Hospital Colorado, Department of Psychiatry \& Neuroscience Program, University of Colorado, Anschutz Medical Campus, 13123 East 16th Avenue, Aurora, CO, 80045

${ }^{3}$ Division of Child and Adolescent Psychiatry, New York State Psychiatric Institute, Department of Psychiatry, Vagelos College of Physicians and Surgeons, Columbia University, 1051 Riverside Drive, New York, NY 10032

${ }^{4}$ Department of Psychology and Neuroscience, University of Colorado Boulder, Boulder, CO, 80309

${ }^{\mathrm{t}}$ Correspondence to:

Simone P. Haller, DPhil

Emotion and Development Branch

National Institute of Mental Health

National Institutes of Health

9000 Rockville Pike

Bethesda, MD, 20892

Phone: 3014518861

Fax: (301) 480-4683

Email: simone.haller@nih.gov

Keywords: ADHD, DMDD, attention, processing efficiency, drift diffusion modeling 
medRxiv preprint doi: https://doi.org/10.1101/2020.04.15.20063578; this version posted April 20, 2020. The copyright holder for this preprint

(which was not certified by peer review) is the author/funder, who has granted medRxiv a license to display the preprint in perpetuity.

This article is a US Government work. It is not subject to copyright under 17 USC 105 and is also made available for use under a CCO license.

Running head: ATTENTIONAL IMPAIRMENTS IN DMDD AND ADHD

\section{Abstract}

Objective: Computational models provide information about cognitive components underlying behavior. When applied to psychopathology-relevant processes, they offer additional insight to observed differences in behavioral performance. Drift diffusion models have been successfully applied to investigate processing efficiency during binary choice tasks. Using these, we examine the association between psychopathology (irritability and inattention) and processing efficiency under different attentional demands.

Method: 187 youth with ADHD, DMDD, both disorders, or no major psychopathology ( $M$ age $=13.09, S D=2.55 ; 34 \%$ female) completed an Eriksen Flanker task. Of these, 87 provided complete data on dimensional measures of the core symptom of DMDD, irritability, and those of ADHD, inattention and hyperactivity.

Results: In a categorical analysis $(n=187)$, we found a ADHD-by-DMDD-by task condition interaction on processing efficiency $(b=-1.07, p=.01,95 \% \mathrm{CI}=[-1.89,-.24])$, where increases in processing efficiency for non-conflict conditions were larger in youth without psychopathology relative to patients. Analysis of symptom severity $(n=87)$ across diagnosis was consistent with the above analysis, revealing an interaction between symptom dimensions and task condition on processing efficiency $(\mathrm{b}=-0.10, p=.018,95 \% \mathrm{CI}[-.18,-.02])$. Inattention, and its combined effect with irritability, predicted the magnitude of difference in processing efficiency between conflict and non-conflict conditions.

Discussion: Reduced processing efficiency may represent a shared cognitive endophenotype between ADHD and DMDD. Youth high in irritability or inattention may have difficulty adjusting processing efficiency to changing task demands possibly reflecting impairments in cognitive flexibility. 
medRxiv preprint doi: https://doi.org/10.1101/2020.04.15.20063578; this version posted April 20, 2020. The copyright holder for this preprint

(which was not certified by peer review) is the author/funder, who has granted medRxiv a license to display the preprint in perpetuity.

This article is a US Government work. It is not subject to copyright under 17 USC 105 and is also made available for use under a CCO license.

Running head: ATTENTIONAL IMPAIRMENTS IN DMDD AND ADHD

\section{Introduction}

Increased reaction time variability on cognitive tasks is among the most replicated behavioral alterations in ADHD (Huang-Pollock, Karalunas, Tam, \& Moore, 2012; Kofler et al., 2013). Recent psychophysical theories suggest that such variability can be explained by processing inefficiency, which explains behavior that is not just more variable in speed but also slower and likely to result in errors (Huang-Pollock et al., 2017). However, reaction time variability may not be specific to ADHD but also observed in other psychiatric phenotypes (Kaiser et al., 2008). Particularly, very little work to date has examined reaction time variability in youth with severe, chronic irritability. Here, we provide evidence from both a categorical and continuous, transdiagnostic approach to demonstrate associations between irritability and attention deficits, reaction time variability, and processing efficiency.

In studying affective psychopathology, examining response time variability may yield important insights into relevant cognitive processing mechanisms in affective (Warren et al., 2020) and nonaffective contexts (Lawlor et al., 2019). The high rate of comorbidity between ADHD and DMDD as well as co-occurrence of irritability and inattention symptoms specifically in clinical populations (Althoff et al., 2016; Kircanski et al., 2017; Mayes, Waxmonsky, Calhoun, \& Bixler, 2016; Pagliaccio et al., 2017), has impeded our examination of the relative contributions of irritability and attentional symptoms to reaction time variability. As noted above, response time variability is a stable feature of ADHD, present across diverse tasks (e.g., reward, cognitive control), with some evidence for moderation of group differences by task difficulty (Epstein et al., 2011). However, advances in computational modeling and clinical phenotyping allow us to examine the associations between irritability, ADHD symptoms, and reaction time variability. 
medRxiv preprint doi: https://doi.org/10.1101/2020.04.15.20063578; this version posted April 20, 2020. The copyright holder for this preprint

(which was not certified by peer review) is the author/funder, who has granted medRxiv a license to display the preprint in perpetuity.

This article is a US Government work. It is not subject to copyright under 17 USC 105 and is also made available for use under a CCO license.

Running head: ATTENTIONAL IMPAIRMENTS IN DMDD AND ADHD

Computational models measure latent cognitive constructs and can reveal mechanismbased psychopathology-related differences in behavioral performance. With regards to response time variability in ADHD, the drift diffusion model (DDM) has been particularly impactful (Karalunas, Huang-Pollock, \& Nigg, 2012; Ziegler, Pedersen, Mowinckel, \& Biele, 2016). The DDM accounts for reaction time, reaction time variability, and accuracy in fast, binary choice tasks (Ratcliff \& McKoon, 2008). It is well-defined with strong theoretical underpinnings and excellent explanatory power for human behavior (Jones, 2017). In the DDM, latent constructs are represented by parameters coding the strength of evidence entering the decision process, the amount of accumulated evidence required to make a decision, as well as motor preparation and output to explain speed-accuracy trade-off effects (Ratcliff \& Tuerlinckx, 2002). Because it accounts for reaction time variability while accounting for all behavior (accuracy and reaction time), the primary parameter of interest for the present study is the drift rate, $v$, generally interpreted as processing efficiency (i.e., a large value represents more rapid, less variable, and error-resistant responses).

In the current study, we compared children diagnosed with ADHD, DMDD, both, or no major psychopathology on their performance on an Erikson flanker task. A subsample of participants also provided dimensional measures of the core symptom of DMDD, irritability, and those of ADHD, inattention and hyperactivity, for a complementary transdiagnostic analysis of symptoms. Based on previous findings (Karalunas et al., 2012; Salum et al., 2014), we expect that youth with ADHD will have lower drift rates relative to healthy volunteers. The Flanker task includes attentional conditions which may facilitate processing or introduce interference; we expect interference to slow processing and therefore reduce drift rates (White, Ratcliff, \& Starns, 2011). Thus, the attentional demands of the flanker task not only allow an examination of 
medRxiv preprint doi: https://doi.org/10.1101/2020.04.15.20063578; this version posted April 20, 2020. The copyright holder for this preprint (which was not certified by peer review) is the author/funder, who has granted medRxiv a license to display the preprint in perpetuity.

This article is a US Government work. It is not subject to copyright under 17 USC 105 and is also made available for use under a CCO license.

Running head: ATTENTIONAL IMPAIRMENTS IN DMDD AND ADHD

associations between irritability and ADHD symptoms and drift rate but also the change in these associations with changing attentional demands. This is first study to systematically investigate response time variability and processing efficiency in DMDD; thus, we are agnostic in our predictions about cognitive control impairments in DMDD only, as the contribution of comorbid ADHD to attention processing in this population remains unclear.

\section{Methods}

\section{Participants}

Two-hundred and twenty-one youth with and without psychopathology (healthy volunteers; HVs) participated in this study. Youth were recruited both locally and nationally through practitioner referrals and IRB approved advertisements. Written informed consent was obtained from parents and assent was obtained from children. The study was approved by the NIMH Institutional Review Board.

Diagnoses were made by master's or doctoral level clinician trained to reliability $(\kappa>0.9)$ using a modified Schedule for Affective Disorders and Schizophrenia for School-Age ChildrenPresent and Lifetime Version (K-SADS-PL; Kaufman et al., 1997) with an additional module to assess presence of DMDD (Wiggins et al., 2016). For all participants, full scale IQ $<70$ (determined by the Wechsler Abbreviated Scale of Intelligence; WASI; Wechsler, 2011), history of head trauma, neurological disorder, pervasive developmental disorder, medical illness preventing study participation, cardinal bipolar symptoms, post-traumatic stress disorder, schizophrenia, schizophreniform disorder, schizoaffective illness, current major depressive disorder or substance abuse within 2 months were exclusionary.

A total of 34 youth were excluded, 32 for task performance (see Methods for criteria), one child was excluded as the model failed to produce valid parameter estimates and one child was 
medRxiv preprint doi: https://doi.org/10.1101/2020.04.15.20063578; this version posted April 20, 2020. The copyright holder for this preprint

(which was not certified by peer review) is the author/funder, who has granted medRxiv a license to display the preprint in perpetuity.

This article is a US Government work. It is not subject to copyright under 17 USC 105 and is also made available for use under a CCO license.

Running head: ATTENTIONAL IMPAIRMENTS IN DMDD AND ADHD

identified as a high leverage value in the multilevel model (Cook's distance $>2.5$ ). Characteristics of the remaining 187 participants are presented in Table 1. Age and Sex did not significantly differ between diagnostic groups. Significant differences in FSIQ emerged across groups.

A subsample of $n=87$ youth (30 youth with ADHD only, 7 youth with DMDD only, 38 youth with DMDD+ADHD and $12 \mathrm{HV}$ youth) also completed the parent-reported Affective Reactivity Index (ARI; Stringaris et al., 2012) and the Conners' Parent Rating Scale (CPRS hyperactive and inattentive subscale, raw scores (Conners, Sitarenios, Parker, \& Epstein, 1998; CPRS - hyperactive and inattentive subscale, raw scores), assessing irritability and ADHD severity, respectively.

\section{Task}

Children were presented with a modified version of the Eriksen Flanker task that used arrows rather than letter stimuli (Erikson \& Erikson, 1974; Scherer, 1994). Five stimuli were arrayed horizontally with a central target (a left or right pointing arrow) and two distractors on each side. Conditions were: 1) congruent: in which distractors were identical to the target; 2) incongruent: in which distractor arrows were pointed opposite to the target; and 3) neutral: in which distractors were squares. Each trial started with a fixation cross $(500 \mathrm{~ms})$ followed by stimuli and response window $(1000 \mathrm{~ms})$ and then a blank screen $(1500 \mathrm{~ms})$. Figure 1 depicts the stimuli and trial sequence. The task was presented as one continuous block of 130 trials, taking 6.5 minutes to complete. Condition order was pseudo-randomly determined to maintain the same frequency for each condition. Each participant experienced the same order of trial condition.

The task was presented via E-Prime 1.1 Build 1.1.4.1 or E-Prime 1.2 Build 1.2.1.847 on a laptop computer running Windows XP version 2002 or Windows 7 Professional. Stimuli arrays 
medRxiv preprint doi: https://doi.org/10.1101/2020.04.15.20063578; this version posted April 20, 2020. The copyright holder for this preprint

(which was not certified by peer review) is the author/funder, who has granted medRxiv a license to display the preprint in perpetuity.

This article is a US Government work. It is not subject to copyright under 17 USC 105 and is also made available for use under a CCO license.

Running head: ATTENTIONAL IMPAIRMENTS IN DMDD AND ADHD

were $5.93 \times 1.22 \mathrm{~cm}$ presented on a laptop placed at a viewing distance of approximately $60 \mathrm{~cm}$. Participants responded to the target's direction with their corresponding index finger, each placed on the laptop's "a" (left) and "l" (right) keys. Children completed a practice task of 30 trials and were trained to $83 \%$ (25/30 correct responses) accuracy before proceeding to the task.

\section{Statistical analyses}

\section{Data preparation}

Task data were prepared for analyses by removing non-physiologic anticipation responses (RT $<150 \mathrm{~ms} ; 0.2 \%$ of all trials) and trials without responses. Participants who performed at or below chance ( $\leq 50 \%$ accuracy on any condition) or were too poorly engaged in the task (an overall non-response rate $\geq 15 \%$ ) were excluded from further analyses $(n=32)$. All analysis was performed in $R$ Version 3.5 using the "lme4" package (Bates et al., 2015).

\section{Drift Diffusion Model}

As a speeded binary choice reaction time paradigm generally completed with high accuracy and speed, the Flanker task is fit for the application of the Drift Diffusion Model. Previous work has successfully used drift diffusion modeling in the analysis of Flanker task data (White et al., 2011). Diffusion parameters were estimated for each condition from all non-missing trials of the task using the full distribution of reaction times (i.e., congruent, incongruent and neural trials, errors). Diffusion parameters were estimated from the trial-by-trial data for each participant using the fast-dm modeling program Version 30.2 (Voss \& Voss, 2007; Voss, Voss, \& Lerche, 2015). For each condition, the model estimated parameters for a correct decision versus an error . Drift rate $(v)$ varied across condition. Boundary separation $(a)$, and non-decision time $(T)$ were 
medRxiv preprint doi: https://doi.org/10.1101/2020.04.15.20063578; this version posted April 20, 2020. The copyright holder for this preprint

(which was not certified by peer review) is the author/funder, who has granted medRxiv a license to display the preprint in perpetuity.

This article is a US Government work. It is not subject to copyright under 17 USC 105 and is also made available for use under a CCO license.

Running head: ATTENTIONAL IMPAIRMENTS IN DMDD AND ADHD

computed for each participant and constant across conditions. Bias, $z r$, was set to 0.5 . The Maximum Likelihood approach was used to estimate fit.

To examine model performance, we compared simulated to the empirical data. We used the construct-samples tool, part of fast-dm, to simulate data sets from participants' specific parameter set. For each participant, one dataset with $n=1000$ trials was simulated for each condition. Group reaction time distributions were constructed by averaging the quantiles of individual reaction time distributions. Given the small number of errors, medians were plotted rather than quantiles (White et al., 2011). Quantile probability plots (Ratcliff \& Tuerlinckx, 2002) are a standard method to represent the distribution of reaction time by accuracy for all conditions in a task. See Figure 2 for a quantile probability plot for five reaction time quartiles $(0.1,0.3,0.5$, 0.7 and 0.9 ) for the empirical and simulated data for all youth.

A multilevel model testing the effects of diagnosis (DMDD and ADHD as separate predictors) and task condition (three level repeated measure) and task condition with Age and FSIQ as covariates and participant as a random effect was used to examine the DMM drift rate (v) parameter of interest. In a smaller sample $(n=87)$, we used similar multilevel models to examined associations between continuous measures of irritability and ADHD (hyperactivity and inattentiveness tested separately) and task condition predicting drift rate with, task condition with Age and FSIQ as covariates. Because the ARI has a floor effect, it was converted to a binary factor representing low or high irritability symptoms. As including Sex in the models did not affect results, the models are presented without this additional covariate.

Supplementary Materials include analyses examining reaction time variability (intrasubject variability of reaction time measured as the coefficient of variation $(\mathrm{CoV})$, the standard 
medRxiv preprint doi: https://doi.org/10.1101/2020.04.15.20063578; this version posted April 20, 2020. The copyright holder for this preprint

(which was not certified by peer review) is the author/funder, who has granted medRxiv a license to display the preprint in perpetuity.

This article is a US Government work. It is not subject to copyright under 17 USC 105 and is also made available for use under a CCO license.

Running head: ATTENTIONAL IMPAIRMENTS IN DMDD AND ADHD

deviation/mean RT for correct responses by condition). We also include analyses exploring the relationship between $\mathrm{CoV}$ and drift rate for each condition using Pearson correlations.

\section{Results}

\section{Diffusion Model Parameters}

As expected response time variability as measured by $\mathrm{CoV}$ was associated with drift rate all $r \mathrm{~s}(185)>-.62, \mathrm{p}<.001$, for each task condition. See Supplementary Materials for an analysis of $\mathrm{CoV}$ and a correlation matrix between drift rate and $\mathrm{CoV}$ by condition (Table S2).

\section{Diagnostic Associations}

For the multivariate categorical analysis of the DDM drift rate parameter (v), a significant DMDD-by-ADHD-by-task condition interaction emerged $(n=187 ; b=-1.07, p=0.01,95 \% \mathrm{CI}=[-$ $1.89,-0.24]$, see Table 2 for full model). Differences emerged such that all patient groups showed lower drift rates compared to youth without psychopathology between non-conflict (neutral and congruent) and conflict conditions (see Figure 3).

\section{Symptom Associations}

Additional analyses were conducted on symptoms in the smaller subsample $(n=87)$. These analyses revealed interactions between both symptom dimensions and task condition on drift rate (see Table 3 for full model). Notably only inattentiveness was associated with reduced drift rate across all task conditions $(\mathrm{b}=-.09, p=.011,95 \% \mathrm{CI}[-.16,-.02])$, while irritability was specific to task condition $(\mathrm{b}=1.64, p=.021,95 \% \mathrm{CI}[.26,-3.02])$. However, similar to the categorical analysis, they interacted such that in combination they did not have purely additive effects. Notably, the two 
medRxiv preprint doi: https://doi.org/10.1101/2020.04.15.20063578; this version posted April 20, 2020. The copyright holder for this preprint

(which was not certified by peer review) is the author/funder, who has granted medRxiv a license to display the preprint in perpetuity.

This article is a US Government work. It is not subject to copyright under 17 USC 105 and is also made available for use under a CCO license.

Running head: ATTENTIONAL IMPAIRMENTS IN DMDD AND ADHD

symptom dimensions interacted with task conditions such that irritability modulated the effects of inattention on drift rate by condition $(\mathrm{b}=-.10, p=.018,95 \% \mathrm{CI}[-.18,-.02])$; see Figure 3$)$.

In the hyperactivity model, hyperactivity was associated with a reduced drift rate $(b=-.09$, $p=.038,95 \% \mathrm{CI}[-.18,-.01])$ similar to the pattern of inattentive symptoms, above, but no other main or interactive effects of symptoms were evident (see Supplementary Table S3 for full model).

For all linear models, all predictors had a corrected generalized variance inflation factor $<5$, suggesting acceptable levels of multicollinearity for analysis.

\section{Discussion}

Here, we conduct the first examination of reaction time variability, via the DDM, in youth with severe irritability accounting for ADHD symptoms. We demonstrate common and distinct associations with drift rate, ADHD, DMDD, and their core symptoms that vary by attentional demands. Consistent with our hypotheses, drift rate, or processing efficiency, decreased by having ADHD or DMDD or being confronted with distractors. Specifically, increases in processing efficiency for non-conflict conditions were larger in youth without psychopathology relative to patients. Analyses of continuous measures in a smaller subsample revealed interactive effects between irritability and inattention on drift rate. Effects appeared particularly pronounced when switching from continuous performance demands to conflict processing (incongruent condition) settings.

As expected, the strong correlations occurred between response variability and the drift rate parameter; lower drift rates will result in a wider distribution of reactions times (Ratcliff \& McKoon, 2008; Wagenmakers, van der Maas, \& Grasman, 2007). This suggests that the increased variability seen in sustained attention tasks in youth with ADHD and DMDD can be partially 
medRxiv preprint doi: https://doi.org/10.1101/2020.04.15.20063578; this version posted April 20, 2020. The copyright holder for this preprint

(which was not certified by peer review) is the author/funder, who has granted medRxiv a license to display the preprint in perpetuity.

This article is a US Government work. It is not subject to copyright under 17 USC 105 and is also made available for use under a CCO license.

Running head: ATTENTIONAL IMPAIRMENTS IN DMDD AND ADHD

explained by less efficient processing. Hence, the computational modeling perspective adds to our understanding of the behavioral dysfunction by bringing interpretational clarity to decision computation impairments observed in ADHD and DMDD. In the case of ADHD, DDM-measured cognitive processing inefficiency support hypotheses of neural processing inefficiency (i.e., lower signal to noise ratio in decision-making networks, Huang-Pollock et al., 2017). Empirically, efforts have been made to combine neural and computational approaches to map neural signals to specific computations captured in latent parameters (Turner, Forstmann, Love, Palmeri, \& Van Maanen, 2017) or even undertake neutrally informed modeling (O'Connell, Shadlen, Wong-Lin, \& Kelly, 2018).

Though much has been written about the involvement of sustained attention on response time variability in ADHD (Huang-Pollock et al., 2012; Karalunas et al., 2012), caution is warranted when interpreting cognitive control functions underlying interindividual differences in reaction time variance (Huang-Pollock et al., 2017). Attentional demands reflect cognitive load influences on processing efficiency (White et al., 2011). Notably, we find associations with diagnostic status were modulated by attentional demands, with the most pronounced associations in conditions of relatively low attentional demand. This may reflect a floor effect on drift rate, where high cognitive load suppresses drift rate to the extent that it obscures symptom associations. On the other hand, it may reflect symptom-related issues with effectively recruiting cognitive resources in conditions which require lower cognitive resources, e.g. cognitive flexibility.

The only previous fMRI study (Pagliaccio et al., 2017) to examine sustained attention in youth with ADHD and DMDD found blunting in parietal attention networks among both patients with ADHD and DMDD associated with longer trial-wise reaction times. Additionally, the study found DMDD-specific increases in pre-stimulus activation associated with longer trial-wise 
medRxiv preprint doi: https://doi.org/10.1101/2020.04.15.20063578; this version posted April 20, 2020. The copyright holder for this preprint

(which was not certified by peer review) is the author/funder, who has granted medRxiv a license to display the preprint in perpetuity.

This article is a US Government work. It is not subject to copyright under 17 USC 105 and is also made available for use under a CCO license.

Running head: ATTENTIONAL IMPAIRMENTS IN DMDD AND ADHD

reaction times in several frontal and parietal regions. Converging with the current findings, this evidence suggests that cognitive control impairments are not specific to ADHD, but also link to DMDD, and perhaps to chronic irritability. Decomposing the cognitive processes of sustained attention reflected in reaction time on the neural level would be a natural next step to aid interpretation of neural findings.

\section{Limitations and future directions}

There are several limitations to consider when interpreting the findings. First, these results may only be generalized to populations able to learn and complete the Flanker task. A number of youth $(\sim 15 \%)$ were unable to train to adequate task performance and were not invited to complete the task. Second, with a correlation of $r=.49, p<.001$, there is significant overlap between the constructs of inattention and irritability, and issues of multicollinearity arise, biasing toward type II error. However, examinations of variance inflation factor found these to within generally acceptable limits $(<5)$ for all terms in all models. Though fast- $d m$ is well validated, it only allows for a constant drift rate. A drift rate that varies with time might better capture early attentional dynamics in the flanker, which are especially prominent in the incongruent condition (White et al. 2011). Examining these variables dimensionally enabled us to explore more fine-grained interactions among symptom domains, as opposed to categorical diagnoses. Such data was available only for a subsample for the current report. However, the current diagnostic comparisons are helpful. They were determined by semi-structured interview including multiple sources of information and arrived at by consensus among experts. They reflect differences in attention/hyperactivity and irritability on which ADHD and DMDD are solely based. Finally, they are highly relevant for clinical practice and directly inform clinicians on the specificity of response time variability to ADHD. Future studies may leverage dimensional data via latent class modeling 
medRxiv preprint doi: https://doi.org/10.1101/2020.04.15.20063578; this version posted April 20, 2020. The copyright holder for this preprint (which was not certified by peer review) is the author/funder, who has granted medRxiv a license to display the preprint in perpetuity.

This article is a US Government work. It is not subject to copyright under 17 USC 105 and is also made available for use under a CCO license.

Running head: ATTENTIONAL IMPAIRMENTS IN DMDD AND ADHD

of clinical variables to examine how response time variability and processing efficiency track with individual differences in irritability and ADHD symptoms. An interesting future direction is examining cognitive control in an affective, rather than a 'cold' cognitive context. Cognitive control processes contribute to the regulation of affective states, i.e. emotional regulation (Ochsner \& Gross, 2005). Current models of chronic, severe irritability posit impairments in cognitive control as a potential mediator for experiences of frustration and behavioral manifestations of irritability, i.e., temper outbursts (Kircanski et al., 2019). Hence, 'cold' cognitive control differences observed in the current study may be magnified in cognitive control tasks where goal conflicts evoke negative affect.

\section{Conclusion}

Applying a computational modeling approach, we can map increased variability in reaction times in ADHD and DMDD onto difficulties in basic processing of stimuli under different attentional demands. Our results suggest that attentional impairments are not specific to ADHD; rather they may represent shared psychopathology between ADHD and DMDD. 
medRxiv preprint doi: https://doi.org/10.1101/2020.04.15.20063578; this version posted April 20, 2020 . The copyright holder for this preprint

(which was not certified by peer review) is the author/funder, who has granted medRxiv a license to display the preprint in perpetuity. This article is a US Government work. It is not subject to copyright under 17 USC 105 and is also made available for use under a CCO license.

Running head: ATTENTIONAL IMPAIRMENTS IN DMDD AND ADHD

\section{References}

Bates, D., Maechler, M., Bolker, B., Walker, S., Christensen, R. H. B., Singmann, H., . . Bolker, M. B. J. C. (2015). Package 'lme4'. 12(1), 2.

Conners, C. K., Sitarenios, G., Parker, J. D., \& Epstein, J. N. (1998). The revised Conners' Parent Rating Scale (CPRS-R): factor structure, reliability, and criterion validity. Journal of Abnormal Child Psychology, 26(4), 257-268.

Epstein, J. N., Langberg, J. M., Rosen, P. J., Graham, A., Narad, M. E., Antonini, T. N., . . Altaye, M. J. N. (2011). Evidence for higher reaction time variability for children with ADHD on a range of cognitive tasks including reward and event rate manipulations. 25(4), 427.

Erikson, B., \& Erikson, C. (1974). Effects of noise letters upon the identification of a target letter in a nonsearch task. 16(1), 143-149.

Huang-Pollock, Karalunas, S. L., Tam, H., \& Moore, A. N. (2012). Evaluating vigilance deficits in ADHD: a meta-analysis of CPT performance. Journal of Abnormal Psychology, 121(2), 360-371. doi:10.1037/a0027205

Huang-Pollock, Ratcliff, R., McKoon, G., Shapiro, Z., Weigard, A., \& Galloway-Long, H. (2017). Using the Diffusion Model to Explain Cognitive Deficits in Attention Deficit Hyperactivity Disorder. Journal of Abnormal Child Psychology, 45(1), 57-68. doi:10.1007/s10802-016-0151-y

Jones, M. (2017). The Diffusion Model of Speeded Choice, from a Rational Perspective.

Kaiser, S., Roth, A., Rentrop, M., Friederich, H. C., Bender, S., \& Weisbrod, M. (2008). Intra-individual reaction time variability in schizophrenia, depression and borderline personality disorder. Brain and Cognition, 66(1), 73-82. doi:10.1016/j.bandc.2007.05.007

Karalunas, S. L., Huang-Pollock, C. L., \& Nigg, J. T. (2012). Decomposing attention-deficit/hyperactivity disorder (ADHD)-related effects in response speed and variability. Neuropsychology, 26(6), 684694. doi:10.1037/a0029936

Kaufman, J., Birmaher, B., Brent, D., Rao, U., Flynn, C., Moreci, P., . . Ryan, N. (1997). Schedule for Affective Disorders and Schizophrenia for School-Age Children-Present and Lifetime Version (K-SADS-PL): initial reliability and validity data. Journal of the American Academy of Child and Adolescent Psychiatry, 36(7), 980-988. doi:10.1097/00004583-199707000-00021

Kircanski, K., Craske, M. G., Averbeck, B. B., Pine, D. S., Leibenluft, E., \& Brotman, M. A. (2019). Exposure therapy for pediatric irritability: Theory and potential mechanisms. Behaviour Research and Therapy, 118, 141-149. doi:10.1016/j.brat.2019.04.007

Kofler, M. J., Rapport, M. D., Sarver, D. E., Raiker, J. S., Orban, S. A., Friedman, L. M., \& Kolomeyer, E. G. (2013). Reaction time variability in ADHD: a meta-analytic review of 319 studies. Clinical Psychology Review, 33(6), 795-811. doi:10.1016/j.cpr.2013.06.001

Lawlor, V. M., Webb, C. A., Wiecki, T. V., Frank, M. J., Trivedi, M., Pizzagalli, D. A., \& Dillon, D. G. J. P. m. (2019). Dissecting the impact of depression on decision-making. 1-10.

O'Connell, R. G., Shadlen, M. N., Wong-Lin, K., \& Kelly, S. P. (2018). Bridging Neural and Computational Viewpoints on Perceptual Decision-Making. Trends in Neurosciences, 41(11), 838-852. doi:10.1016/j.tins.2018.06.005

Ochsner, K. N., \& Gross, J. J. (2005). The cognitive control of emotion. Trends in Cognitive Sciences, 9(5), 242-249. doi:10.1016/j.tics.2005.03.010

Pagliaccio, D., Wiggins, J. L., Adleman, N. E., Curhan, A., Zhang, S., Towbin, K. E., . . Leibenluft, E. (2017). Behavioral and Neural Sustained Attention Deficits in Disruptive Mood Dysregulation Disorder and Attention-Deficit/Hyperactivity Disorder. Journal of the American Academy of Child and Adolescent Psychiatry, 56(5), 426-435. doi:10.1016/j.jaac.2017.02.008

Ratcliff, R., \& McKoon, G. (2008). The diffusion decision model: theory and data for two-choice decision tasks. Neural Computation, 20(4), 873-922. doi:10.1162/neco.2008.12-06-420

Ratcliff, R., \& Tuerlinckx, F. (2002). Estimating parameters of the diffusion model: approaches to dealing with contaminant reaction times and parameter variability. Psychon Bull Rev, 9(3), 438-481. doi:10.3758/bf03196302 
medRxiv preprint doi: https://doi.org/10.1101/2020.04.15.20063578; this version posted April 20, 2020 . The copyright holder for this preprint

(which was not certified by peer review) is the author/funder, who has granted medRxiv a license to display the preprint in perpetuity. This article is a US Government work. It is not subject to copyright under 17 USC 105 and is also made available

Running head: ATTENTIONAL IMPAIRMENTS IN DMDD AND ADHD

Salum, G. A., Sonuga-Barke, E., Sergeant, J., Vandekerckhove, J., Gadelha, A., Moriyama, T. S., .. . Rohde, L. A. (2014). Mechanisms underpinning inattention and hyperactivity: neurocognitive support for ADHD dimensionality. Psychological Medicine, 44(15), 3189-3201. doi:10.1017/S0033291714000919

Scherer, K. R. (1994). Emotion serves to decouple stimulus and response. The nature of emotion: Fundamental questions, 127-130.

Stringaris, A., Goodman, R., Ferdinando, S., Razdan, V., Muhrer, E., Leibenluft, E., \& Brotman, M. A. (2012). The Affective Reactivity Index: a concise irritability scale for clinical and research settings. Journal of Child Psychology and Psychiatry, 53(11), 1109-1117.

Turner, B. M., Forstmann, B. U., Love, B. C., Palmeri, T. J., \& Van Maanen, L. (2017). Approaches to analysis in model-based cognitive neuroscience. Journal of Mathematical Psychology, 76, 65-79. doi:10.1016/j.jmp.2016.01.001

Voss, A., \& Voss, J. (2007). Fast-dm: a free program for efficient diffusion model analysis. Behavior Research Methods, 39(4), 767-775. doi:10.3758/bf03192967

Voss, A., Voss, J., \& Lerche, V. (2015). Assessing cognitive processes with diffusion model analyses: a tutorial based on fast-dm-30. Front Psychol, 6, 336. doi:10.3389/fpsyg.2015.00336

Wagenmakers, E. J., van der Maas, H. L., \& Grasman, R. P. (2007). An EZ-diffusion model for response time and accuracy. Psychon Bull Rev, 14(1), 3-22. doi:10.3758/bf03194023

Warren, S. L., Zhang, Y., Duberg, K., Mistry, P., Cai, W., Qin, S., . . Menon, V. J. B. P. (2020). Anxiety and stress alter decision-making dynamics and causal amygdala-dorsolateral prefrontal cortex circuits during emotion regulation in children.

Wechsler, D. (2011). WASI-II: Wechsler abbreviated scale of intelligence: PsychCorp.

White, C. N., Ratcliff, R., \& Starns, J. J. (2011). Diffusion models of the flanker task: discrete versus gradual attentional selection. Cognitive Psychology, 63(4), 210-238. doi:10.1016/j.cogpsych.2011.08.001

Wiggins, J. L., Brotman, M. A., Adleman, N. E., Kim, P., Oakes, A. H., Reynolds, R. C., .. Leibenluft, E. (2016). Neural Correlates of Irritability in Disruptive Mood Dysregulation and Bipolar Disorders. American Journal of Psychiatry, 173(7), 722-730. doi:10.1176/appi.ajp.2015.15060833

Ziegler, S., Pedersen, M. L., Mowinckel, A. M., \& Biele, G. (2016). Modelling ADHD: A review of ADHD theories through their predictions for computational models of decision-making and reinforcement learning. Neuroscience and Biobehavioral Reviews, 71, 633-656.

doi:10.1016/j.neubiorev.2016.09.002 
medRxiv preprint doi: https://doi.org/10.1101/2020.04.15.20063578; this version posted April 20, 2020. The copyright holder for this preprint (which was not certified by peer review) is the author/funder, who has granted medRxiv a license to display the preprint in perpetuity.

This article is a US Government work. It is not subject to copyright under 17 USC 105 and is also made available for use under a CCO license.

Running head: ATTENTIONAL IMPAIRMENTS IN DMDD AND ADHD

\section{Conditions}
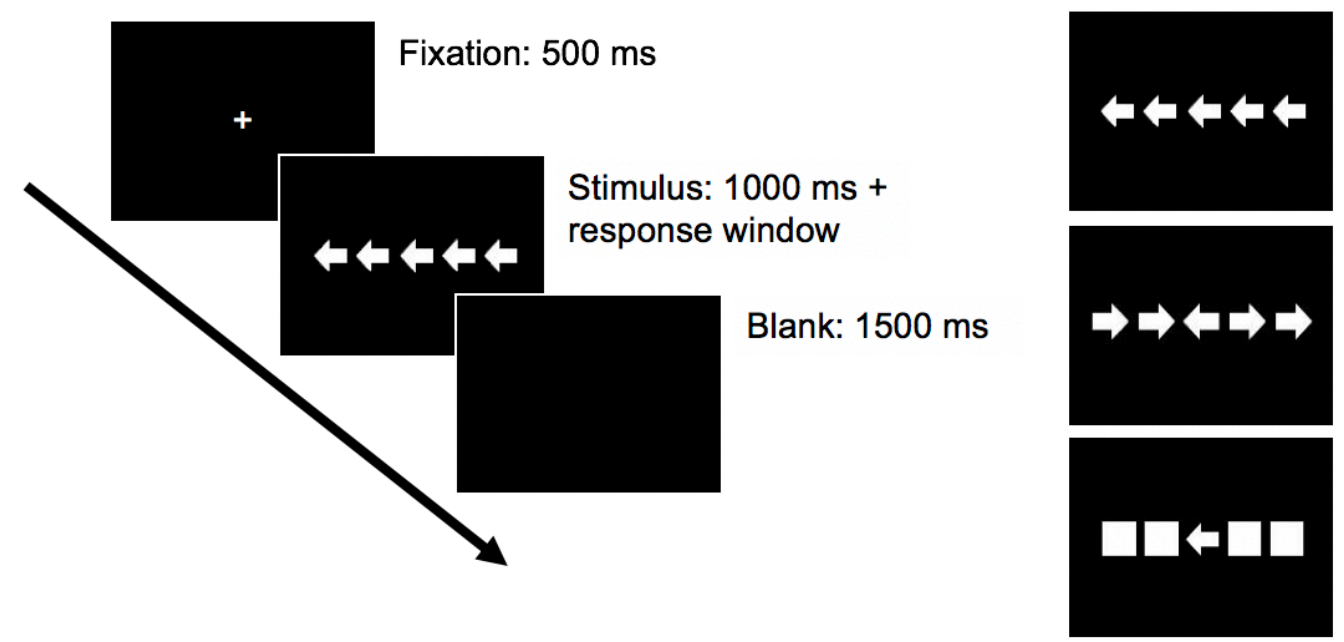

Congruent

Neutral

Figure 1. Trial sequence of the modified Eriksen Flanker task. Each trial started with a fixation cross followed by the stimulus presentation. A blank screen was presented between trials. 
medRxiv preprint doi: https://doi.org/10.1101/2020.04.15.20063578; this version posted April 20, 2020. The copyright holder for this preprint (which was not certified by peer review) is the author/funder, who has granted medRxiv a license to display the preprint in perpetuity.

This article is a US Government work. It is not subject to copyright under 17 USC 105 and is also made available for use under a CCO license.

Running head: ATTENTIONAL IMPAIRMENTS IN DMDD AND ADHD
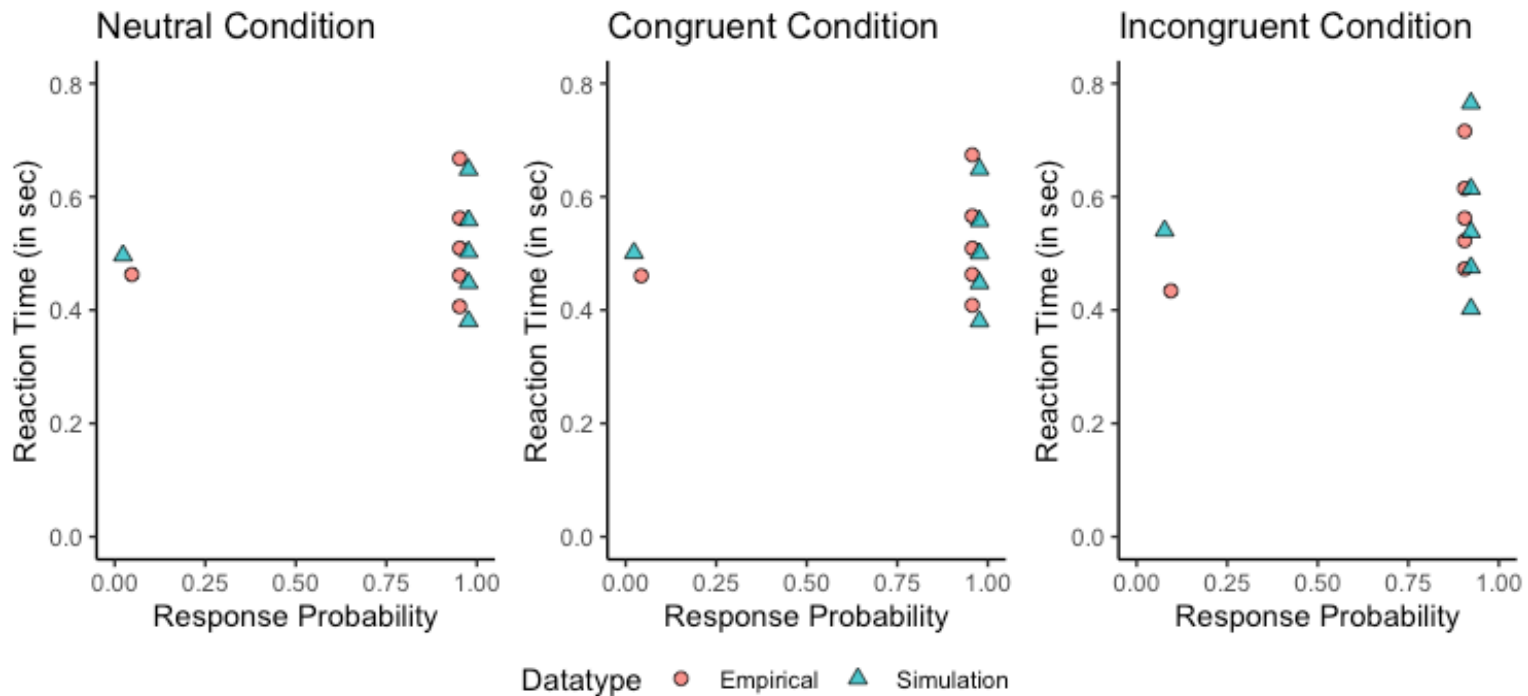

Figure 2. Quantile probability plot for pooled data from all youth. For each condition, the 0.1, $0.3,0.5,0.7$, and 0.9 quantiles of reaction time are averaged across participants or simulations of their parameter set. Correct responses are on the right of each panel and represent almost all responses (average accuracy $>92 \%$ by condition). Overall, the model reasonably represents behavior, especially in the neutral and congruent conditions. In the incongruent condition, the model underestimates the fastest $30 \%$ of reaction times, especially the fastest $10 \%$. This is expected as attention dynamics that represent early interference effects on the drift rate are not represented with a constant drift rate (White et al., 2011). 
medRxiv preprint doi: https://doi.org/10.1101/2020.04.15.20063578; this version posted April 20, 2020. The copyright holder for this preprint (which was not certified by peer review) is the author/funder, who has granted medRxiv a license to display the preprint in perpetuity.

This article is a US Government work. It is not subject to copyright under 17 USC 105 and is also made available for use under a CCO license.

Running head: ATTENTIONAL IMPAIRMENTS IN DMDD AND ADHD

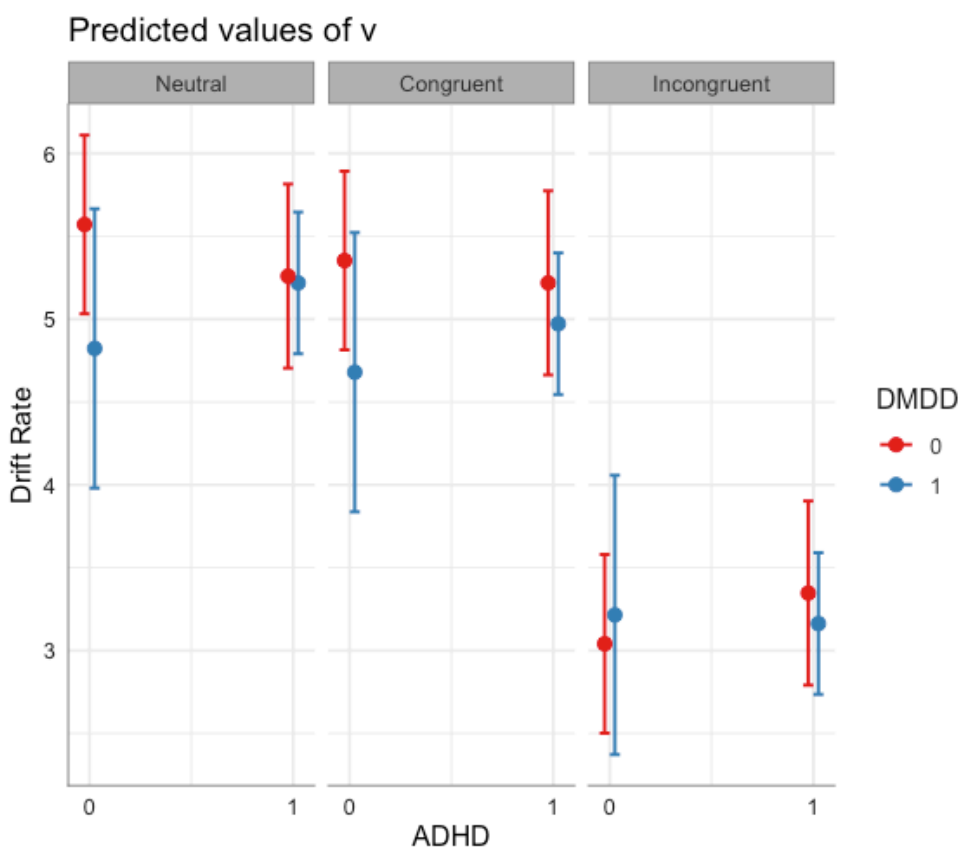

Figure 3. Effects of diagnostic status and task condition on drift rate $v$, adjusted for FSIQ and Age. For diagnostic codings, $1=$ Present and $0=$ Absent. Drift rate is lower in the incongruent condition relative to both neutral and congruent conditions. Differences between those with ADHD or DMDD are evident in the neutral and congruent condition. Error bars reflect 95\% CI. 
medRxiv preprint doi: https://doi.org/10.1101/2020.04.15.20063578; this version posted April 20, 2020. The copyright holder for this preprint (which was not certified by peer review) is the author/funder, who has granted medRxiv a license to display the preprint in perpetuity.

This article is a US Government work. It is not subject to copyright under 17 USC 105 and is also made available for use under a CCO license.

Running head: ATTENTIONAL IMPAIRMENTS IN DMDD AND ADHD

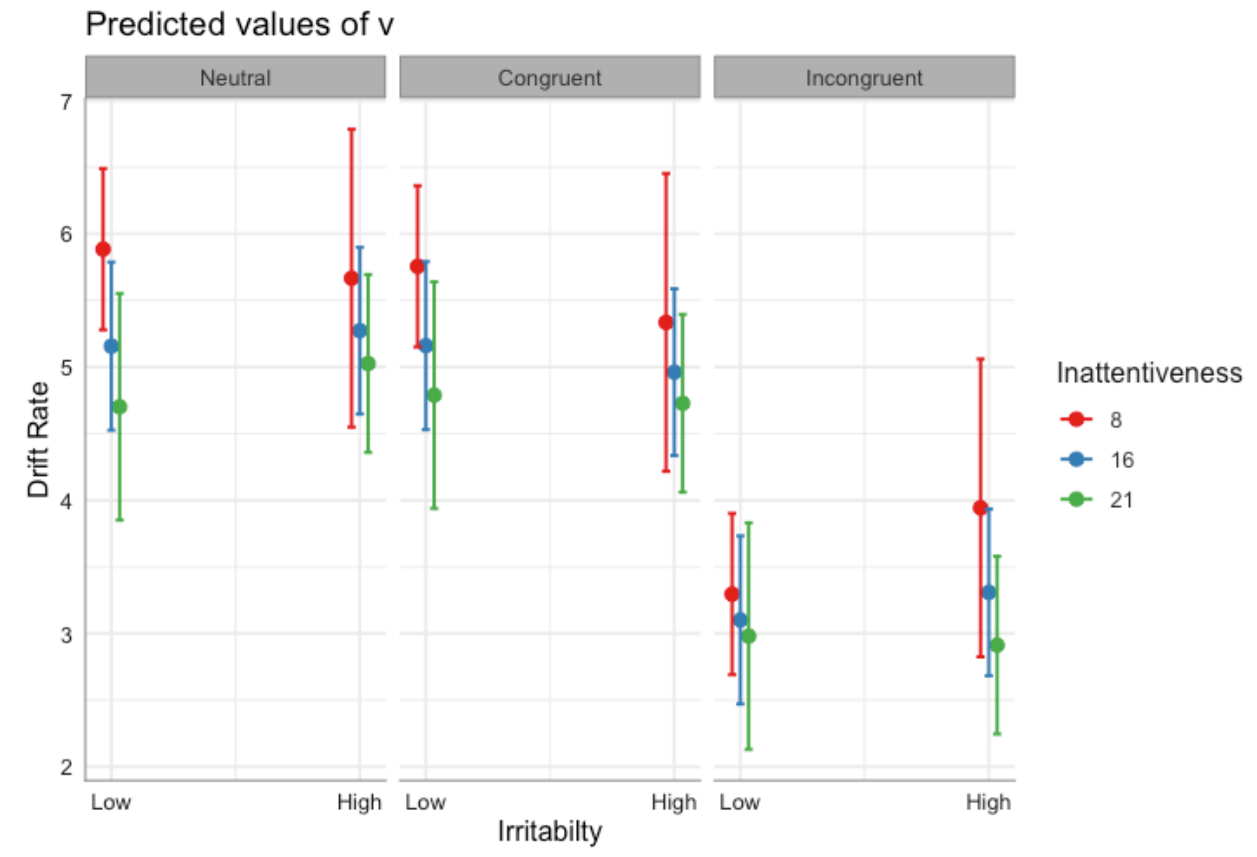

Figure 4. Effects of dimensionally-assessed irritability and inattention and task condition on drift rate $v$, adjusted for FSIQ and Age. Error bars reflect 95\% CI. Increased CIs estimated for youth high in irritability and low in inattention are due to the moderate correlation among symptom domains. 
medRxiv preprint doi: https://doi.org/10.1101/2020.04.15.20063578; this version posted April 20, 2020. The copyright holder for this preprint (which was not certified by peer review) is the author/funder, who has granted medRxiv a license to display the preprint in perpetuity.

This article is a US Government work. It is not subject to copyright under 17 USC 105 and is also made available for use under a CCO license.

Running head: ATTENTIONAL IMPAIRMENTS IN DMDD AND ADHD

Table 1 Sample characteristics by diagnostic group

\begin{tabular}{|c|c|c|c|c|c|c|c|}
\hline & HV & $\begin{array}{l}\text { ADHD } \\
\text { only }\end{array}$ & $\begin{array}{l}\text { DMDD } \\
\text { only }\end{array}$ & $\begin{array}{l}\text { DMDD } \\
+ \\
\text { ADHD }\end{array}$ & Test Statistic & $P$ & Post-hocs $^{\mathrm{a}}$ \\
\hline $\mathrm{N}$ & 47 & 44 & 19 & 77 & & & \\
\hline $\begin{array}{l}\text { Age } \\
\text { M(SD) } \\
\text { yrs }\end{array}$ & $\begin{array}{l}13.61 \\
(2.55)\end{array}$ & $\begin{array}{l}12.95 \\
(2.59)\end{array}$ & $\begin{array}{l}12.95 \\
(2.90)\end{array}$ & $\begin{array}{l}12.88 \\
(2.43)\end{array}$ & $F(3,183)=0.90$ & .45 & \\
\hline $\begin{array}{l}\text { Sex } \\
(\% F)\end{array}$ & 43 & 27 & 53 & 27 & $\chi^{2}(3)=6.93$ & .07 & \\
\hline IQ $M(\mathrm{SD})$ & $113(15)$ & $\begin{array}{l}115 \\
(12)\end{array}$ & $\begin{array}{l}114 \\
(10)\end{array}$ & $\begin{array}{l}108 \\
(13)\end{array}$ & $F(3,183)=3.09$ & .02 & $\begin{array}{l}\text { ADHD, HV> } \\
\text { DMDD+ADHD, } \\
\text { DMDD }\end{array}$ \\
\hline Accuracy & $\begin{array}{l}0.99 \\
(0.02)\end{array}$ & $\begin{array}{l}0.98 \\
(0.03)\end{array}$ & $\begin{array}{l}0.99 \\
(0.02)\end{array}$ & $\begin{array}{l}0.98 \\
(0.03)\end{array}$ & $F(3,183)=2.28$ & .08 & \\
\hline $\begin{array}{l}\text { Mean RT } \\
\text { (correct) }\end{array}$ & $\begin{array}{l}491.15 \\
(80.60)\end{array}$ & $\begin{array}{l}503.45 \\
(77.83)\end{array}$ & $\begin{array}{l}511.81 \\
(73.21)\end{array}$ & $\begin{array}{l}509.91 \\
(73.99)\end{array}$ & $F(3,183)=0.66$ & .58 & \\
\hline
\end{tabular}

Note. HV: healthy controls, ADHD: attention dysregulation/hyperactivity disorder, DMDD: disruptive mood dysregulation disorder aPairwise comparisons using t-tests with pooled SD at $p<.05$. 
medRxiv preprint doi: https://doi.org/10.1101/2020.04.15.20063578; this version posted April 20, 2020. The copyright holder for this preprint

(which was not certified by peer review) is the author/funder, who has granted medRxiv a license to display the preprint in perpetuity.

This article is a US Government work. It is not subject to copyright under 17 USC 105 and is also made available for use under a CCO license.

Running head: ATTENTIONAL IMPAIRMENTS IN DMDD AND ADHD

Table 2. Mixed model regression table for drift rate predicted by diagnostic classification.

\begin{tabular}{lccc} 
& \multicolumn{3}{c}{$\mathbf{v}$} \\
Predictors & Estimates & $C I$ & $p$ \\
\hline Intercept & -4.15 & $-7.15--1.14$ & $\mathbf{0 . 0 0 7}$ \\
ADHD & -0.31 & $-1.08-0.46$ & 0.430 \\
DMDD & -0.75 & $-1.75-0.25$ & 0.144 \\
Condition [Congruent] & -0.22 & $-0.58-0.14$ & 0.240 \\
Condition [Incongruent] & -2.53 & $-2.89--2.17$ & $<\mathbf{0 . 0 0 1}$ \\
Age & 0.42 & $0.32-0.52$ & $<\mathbf{0 . 0 0 1}$ \\
FSIQ & 0.04 & $0.02-0.06$ & $<\mathbf{0 . 0 0 1}$ \\
ADHD * DMDD & 0.71 & $-0.52-1.93$ & 0.258 \\
ADHD * Condition & 0.18 & $-0.34-0.70$ & 0.507 \\
[Congruent] & & & \\
ADHD * Condition & 0.62 & $0.10-1.14$ & $\mathbf{0 . 0 2 1}$ \\
[Incongruent] & & & \\
DMDD * Condition & 0.07 & $-0.60-0.75$ & 0.829 \\
[Congruent] & & & \\
DMDD * Condition & 0.92 & $0.25-1.60$ & $\mathbf{0 . 0 0 8}$ \\
[Incongruent] & & & \\
(ADHD * DMDD ) & -0.28 & $-1.10-0.54$ & 0.505 \\
Condition [Congruent] & & & \\
(ADHD * DMDD) * & -1.07 & $-1.89--0.24$ & $\mathbf{0 . 0 1 2}$ \\
Condition [Incongruent] & & &
\end{tabular}

\section{Random Effects}

\begin{tabular}{ll}
$\sigma^{2}$ & 0.80 \\
$\tau_{00}$ subject & 2.70 \\
ICC & 0.77 \\
$\mathrm{~N}_{\text {Subject }}$ & 187 \\
\hline Observations & 561 \\
Marginal $\mathrm{R}^{2} /$ Conditional $\mathrm{R}^{2}$ & $0.373 / 0.857$
\end{tabular}


medRxiv preprint doi: https://doi.org/10.1101/2020.04.15.20063578; this version posted April 20, 2020. The copyright holder for this preprint (which was not certified by peer review) is the author/funder, who has granted medRxiv a license to display the preprint in perpetuity.

This article is a US Government work. It is not subject to copyright under 17 USC 105 and is also made available for use under a CCO license.

Running head: ATTENTIONAL IMPAIRMENTS IN DMDD AND ADHD

a. References levels for factor contrasts are ADHD is absent, DMDD is absent, and Flanker condition is "Neutral." 
medRxiv preprint doi: https://doi.org/10.1101/2020.04.15.20063578; this version posted April 20, 2020. The copyright holder for this preprint

(which was not certified by peer review) is the author/funder, who has granted medRxiv a license to display the preprint in perpetuity.

This article is a US Government work. It is not subject to copyright under 17 USC 105 and is also made available for use under a CCO license.

Running head: ATTENTIONAL IMPAIRMENTS IN DMDD AND ADHD

Table 3. Mixed effects model regression table for drift rate predicted by symptom dimension.

\begin{tabular}{|c|c|c|c|}
\hline Predictors & Estimates & $\begin{array}{l}\mathbf{v} \\
C I\end{array}$ & $p$ \\
\hline (Intercept) & -4.13 & $-8.55-0.30$ & 0.071 \\
\hline ARI [High] & -0.55 & $-2.64-1.54$ & 0.606 \\
\hline Inattentiveness & -0.09 & $-0.16--0.02$ & 0.011 \\
\hline Condition [Congruent] & -0.26 & $-0.91-0.38$ & 0.428 \\
\hline Condition [Incongruent] & -3.12 & $-3.77--2.48$ & $<0.001$ \\
\hline Age & 0.44 & $0.28-0.60$ & $<0.001$ \\
\hline FSIQ & 0.05 & $0.02-0.07$ & 0.003 \\
\hline $\begin{array}{l}\text { ARI [High] } * \\
\text { Inattentiveness }\end{array}$ & 0.04 & $-0.08-0.16$ & 0.492 \\
\hline $\begin{array}{l}\text { ARI [High] * } \\
\text { Condition [Congruent] }\end{array}$ & -0.09 & $-1.47-1.29$ & 0.898 \\
\hline $\begin{array}{l}\text { ARI [High] } * \\
\text { Condition [Incongruent] }\end{array}$ & 1.64 & $0.26-3.02$ & 0.021 \\
\hline $\begin{array}{l}\text { Inattentiveness * } \\
\text { Condition [Congruent] }\end{array}$ & 0.02 & $-0.03-0.06$ & 0.485 \\
\hline $\begin{array}{l}\text { Inattentiveness * } \\
\text { Condition [Incongruent] }\end{array}$ & 0.07 & $0.02-0.11$ & 0.006 \\
\hline $\begin{array}{l}\text { (ARI [High] } * \\
\text { Inattentiveness) } * \\
\text { Condition [Congruent] }\end{array}$ & -0.01 & $-0.09-0.07$ & 0.729 \\
\hline $\begin{array}{l}\text { (ARI [High] } * \\
\text { Inattentiveness) } * \\
\text { Condition [Incongruent] }\end{array}$ & -0.10 & $-0.18--0.02$ & 0.018 \\
\hline \multicolumn{4}{|l|}{ Random Effects } \\
\hline$\sigma^{2}$ & 0.83 & & \\
\hline$\tau_{00 \text { Subject }}$ & 2.69 & & \\
\hline $\mathrm{ICC}$ & 0.76 & & \\
\hline $\mathrm{N}_{\text {Subject }}$ & 87 & & \\
\hline
\end{tabular}


medRxiv preprint doi: https://doi.org/10.1101/2020.04.15.20063578; this version posted April 20, 2020. The copyright holder for this preprint (which was not certified by peer review) is the author/funder, who has granted medRxiv a license to display the preprint in perpetuity.

This article is a US Government work. It is not subject to copyright under 17 USC 105 and is also made available for use under a CCO license.

Running head: ATTENTIONAL IMPAIRMENTS IN DMDD AND ADHD

Observations 261

Marginal R² Conditional R $\mathrm{R}^{2} \quad 0.436 / 0.867$

a. References levels for factor contrasts low ARI score (median split), and Flanker condition is "Neutral." 